Pregledni rad UDK 2-11:141.78(045)Vattimo, G. doi: $10.21464 /$ fi36209 Primljeno 23. 3. 2016 .

\title{
Zoran Turza
}

Hrvatsko katoličko sveučilište, Ilica 242, HR-10000 Zagreb

zoranturza@yahoo.com

\section{Odjeci radikalne teologije u nereligioznom kršćanstvu Giannija Vattima}

\begin{abstract}
Sažetak
U središtu istraživanja ovoga rada je odnos između »slabe misli« Giannija Vattima i teološkog pokreta poznatog pod nazivom »radikalna teologija« ili »teologija Božje smrti«. Prvi dio donosi pregled glavnih predstavnika radikalne teologije, koja nastoji raskinuti s klasičnom teologijom za koju smatra da polazi od transcendentnog i dalekog Boga. Zatim se, $u$ drugom dijelu, iznosi pregled triju Vattimovih tema iz područja filozofije religije koje se podudaraju s glavnim temama radikalne teologije: nereligiozno kršćanstvo, kenoza i Crkva. Nereligiozno kršćanstvo kao oslobođenje od svakog oblika autoriteta fungira kao proširenje teze radikalne teologije o oslobođenju od klasičnog pristupa Bogu. S druge strane, za Vattima kenoza kao samoispražnjenje Boga Oca potvrđuje oslabljivanje jakih priča moderne, kao i klasičnog modela Crkve, dok unutar radikalne teologije kenoza potvrđuje smrt Boga.

Ključne riječi

smrt Boga, radikalna teologija, Gianni Vattimo, nereligiozno kršćanstvo, kenoza
\end{abstract}

\section{Uvod}

Niti jedna filozofsko-teološka analiza vjere ne bi smjela izbjeći sučeljavanje s kritikom kršćanstva Friedricha Nietzschea koji je na fragmentarno-pjesnički način izrazio ono što je u njegovom vremenu već bilo sazrjelo: Bog, kakvog ga je on poznavao, je mrtav. Njegova je kritika kršćanstva u potpunosti zaživjela nakon propasti temeljnih zasada moderne u Prvom svjetskom ratu. Vrijednosti prosvjetiteljstva su u strahotama Prvog svjetskog rata doživjele katastrofu koja se još više produbila Drugim svjetskim ratom. Čovjek moderne izgubio je vlastite temelje bez obzira jesu li bili humanističke ili pak kršćanske provenijencije. Stoga je sasvim razumljiva pojava egzistencijalizma koji je dezorijentiranom čovjeku moderne pronašao okvir unutar kojega može pronaći neko utemeljenje, bilo ono u slobodi, samom subjektu ili pak u nečemu drugome.

Također, s odmakom od pedesetak godina, moguće je shvatiti pojavu i širenje ateizma nakon genocida nad Židovima u strahotnim nacističkim logorima smrti. Filozofija i teologija uviđaju neodrživost klasičnih temeljnih premisa koje su funkcionirale početkom 20. stoljeća. U teologiji se nakon Drugog svjetskog rata pristupa fenomenu ateizma ne više na autoritativno-apologetski način kakav je obilježio ranija povijesna razdoblja, nego na dijaloškoafirmativan način na Drugom vatikanskom saboru i u »radikalnoj teologiji«. »Teologija Božje smrti« ili »radikalna teologija« naziv je za teološki pokret protestantskih teologa šezdesetih godina prošlog stoljeća koji je teološki afir- 
mirao Nietzscheov proglas Božje smrti i izgradio svojevrsno imanentno teološko tumačenje svijeta i čovjeka u njemu. Jedan od autora čije su teze bliske tezama radikalne teologije je talijanski filozof Gianni Vattimo. U ovome radu nastojimo pokazati na kakav način se i u kojoj mjeri mogu razmišljanja Giannija Vattima, koja zadiru u područja filozofije religije, smjestiti unutar fenomena radikalne teologije, čime želimo doprinijeti boljem razumijevanju osnovnih polazišta Vattimove misli i temeljnih postavki suvremenih rasprava koja se dotiču ključnih tema radikalne teologije. ${ }^{1}$

\section{Radikalna teologija}

Radikalna teologija je teologija koja radikalno prekida s klasičnom teološkom tradicijom koja tumači svijet i čovjeka polazeći od Boga kakav nadilazi ljudsku stvarnost. U prvom redu kritizira Boga klasične kršćanske tradicije da bi afirmiranjem Božje smrti izgradila teologiju blisku suvremenom čovjeku. Glavni zastupnici teologije Božje smrti su: Thomas Altizer, William Hamilton, John Robinson, Gabriel Vahanian, Paul van Buren i Richard Rubenstein, koji nisu jedinstveni po pitanju temeljnih teoloških ideja i principa. ${ }^{2}$

Već je 1961. William Hamilton napisao djelo The New Essence of Christianity $^{3}$ u kojem jasno naznačuje da je klasična slika Boga neodrživa pred suvremenim problematiziranjem zla u svijetu, odnosno, kako je pred patnjama i neprilikama Drugog svjetskog rata Bog utihnuo. Prisutni i bliski Bog koji je već u starozavjetnom shvaćanju pokazao svoju nazočnost u prijateljevanju s Izabranim narodom, koja je kulminirala u novozavjetnom navještaju prisutnog Boga u Isusu iz Nazareta, postao je sada odsutni Bog. Zanimanje za radikalnu teologiju je šezdesetih godina, zbog utjecaja koji su izvršili mediji, naglo poraslo. Naime, tjedni časopis Time je na svojoj naslovnici 8. travnja 1966. donio naslov »Je li Bog mrtav?«. ${ }^{4}$ Ispostavilo se kako bi bez ovakve javne propagande radikalna teologija teško postala, barem u tih nekoliko godina, ključnom temom u javnom i stručnom teološkom smislu. Nadalje, također 1961., Gabriel Vahanian izdao je djelo The Death of God u kojem izražava uvjerenje svojega vremena o gubitku vjere u Boga, na temelju čega se može razumjeti mentalitet i kultura zapadnog čovjeka. Polazi od teze da se nalazimo ne u antikršćanskoj, nego u postkršćanskoj eri. ${ }^{5}$ Vahanian smatra da je nužno da se teologija, na tragu dijalektičke teologije Karla Bartha, okrene apsolutnom Bogu koji u postkršćanskoj eri jedini može spasiti čovjeka.

Pojavila se još jedna publikacija koja je prethodila Altizerovom ključnom tekstu. Naime, Paul van Buren, učenik Rudolpha Bultmanna, napisao je 1963. knjigu The Secular Meaning of the Gospel pod utjecajem analitičke filozofije i logičkog pozitivizma. Van Buren glavnim kriterijem verifikacije teoloških izričaja smatra logičko-lingvističku metodu. Cilj mu je bio istražiti što čovjek misli i podrazumijeva kada koristi jezik vjere. ${ }^{6}$ Za razliku od Rudolpha Bultmanna i Schuberta Ogdena koji, prema van Burenu, istražuju na koji način ateist može razumjeti kršćansku poruku, van Buren se pita:

»Kako kršćanin koji je sam sekularni čovjek shvaća svoju vjeru na sekularni način? «7

Na taj način, stavlja novi zadatak pred teologiju: iznova promisliti svoje izričaje ako želi da oni imaju neko značenje.

Iste godine anglikanski biskup John Robinson napisao je knjigu Honest to God kojom također izražava iskustvo svojih suvremenika: u ateističkom ozračju potreban je drugačiji govor o Bogu. Robinsonova knjiga, iako ne donosi sustavno i dobro obrađena teološka rješenja, ipak pobuđuje veliku pozornost $u$ 
anglosaksonskom svijetu jer je zajednički osjećaj pred ateizmom i sekularizacijom, svojevrsni bon sens Zapada, vješto prikazao u svojoj knjizi. Možemo istaknuti da njegovo djelo ipak omogućava uvid u općedruštveno nezadovoljstvo vjerom koja se suvremenom čovjeku činila dalekom. Svi ključni elementi kršćanskog bića se, prema Robinsonu, smještaju u odnos prema drugome. Euharistija, liturgija i molitva imaju smisla ako se otvaraju drugome.

U židovskoj teologiji pojavila se 1966. značajna knjiga After Auschwitz: Radical Theology and Contemporary Judaism u kojoj Richard Rubenstein temeljito propituje vjeru u Boga koji je gospodar povijesti i Boga saveza u odnosu prema iskustvu Auschwitza. Prema Rubensteinovom mišljenju potrebno je napustiti shvaćanje Boga klasičnog židovstva kao Svemogućega i okrenuti se novim, poganskim, putevima razumijevanja Boga.

Nakon ovih najznačajnijih tekstova radikalne teologije iz šezdesetih godina prošlog stoljeća uslijedilo je mnoštvo publikacija koje su kritički istraživale njihove prednosti i nedostatke. ${ }^{8}$ Glavne ideje ovog teološkog pokreta na specifičan način prisutne su i u filozofsko-teološkim raspravama Giannija Vattima.

Glavni Vattimovi tekstovi, koji obrađuju pitanja i probleme iz područja filozofije religije, sljedeći su: Gianni Vattimo, After Christianity, Columbia University Press, New York 2002. doi: https://doi.org/10.7312/vatt10628; Richard Rorty, Gianni Vattimo, The Future of Religion, Columbia University Press, New York 2005.; John Caputo, Gianni Vattimo, After the Death of God, Columbia University Press, New York 2007.; Đani Vatimo [Gianni Vattimo], Vjerovati da vjeruješ, Fedon, Beograd 2009. Osim toga izdvajamo i nekoliko najznačajnijih suvremenih filozofsko-teoloških rasprava o religijskim temama: Slavoj Žižek, O vjerovanju. Nemilosrdna ljubav, Algoritam, Zagreb 2007.; Slavoj Žižek, John Milbank, The Monstrosity of Christ. Paradox or Dialectic?, Massachusetts Institute of Technology, London 2009.; Don Cupitt, Radical Theology, Polebridge Press, Santa Rosa 2006.; Frederiek Depoortere, The Death of God: An Investigation into History of Western Concept of God, T\&T Clark, London 2008.; Terrry Eagleton, Kultura i smrt Boga, Naklada Ljevak, Zagreb 2012.

Usp. Thomas Altizer, The Gospel of Christian Atheism, Westminster Press, Philadelphia 1966.; Thomas Altizer, William Hamilton, Radical Theology and The Death of God, Bobbs-Merril Company, Indianapolis, New York 1966.; John Robinson, Honest to God, Westminster John Knox Press, Louisville 2006.; Gabriel Vahanian, The Death of God. The Culture of Our Post-Christian Era, Wipf \& Stock Pub, Oregon 2009.; Paul van Buren, The Secular Meaning of the Gospel. Based on an Analysis of its Language, S.C.M., London 1969.; Richard Rubenstein, After Auschwitz: Radical Theology and Contemporary Judaism, MacMillan Pub Co, Indianapolis 1966.
3

Hamilton svojim nazivom knjige »Nova bit kršćanstva« aludira na djelo Ludwiga Feurbacha »Bit kršćanstva« iz 1841. Usp. William Hamilton, The New Essence of Christianity, Association Press, New York 1966.

U tom broju je po prvi puta Time stavio naslovnicu bez slike. Na crnoj podlozi crvenim slovima provokativno je upitao »Je li Bog mrtav? « čime je ušao u antologiju najšokantnijih naslovnica.

5

Usp. G. Vahanian, The Death of God. The Culture of Our Post-Christian Era, str. 228231.

6

Usp. P. van Buren, The Secular Meaning of the Gospel. Based on an Analysis of its Language, str. 3 .

7

Ibid., str. 11.

8

Vidi napose sljedeće tekstove: John Cooper, The Roots of the Radical Theology, Westminster Press, Philadelphia 1967.; Jackson Ice, John Carey (ur.), The Death of God Debate, Westminster Press, Philadelphia 1967.; John W. Montgomery, The 'Is God Dead? ' Controversy, Zondervan Publishing House, Michigan 1966.; Thomas W. Ogletree, The 'Death of God' Controversy, S. C. M., London 1966.; Kenneth Hamilton, God is Dead: The Anatomy of Slogan, Grand Rapids, Michigan 1966.; Billy Graham, Is God Dead?, Grand Rapids, Michigan 1966.; Bernard Murchland, The Meaning of the Death of God, Vintage Books, New York 1967. 


\section{2. »Slaba misao« Giannija Vattima}

Pitamo se na koji se način filozofija Giannija Vattima, poznatija pod nazivom »slaba misao«, referira na glavne teze radikalne teologije. Vattimo bi se mogao, u prvom redu, smjestiti u kontekst postmoderne filozofije i teologije koja izbjegava bilo kakve čvrste metafizičke pozicije. Ponajprije nas zanima odnos radikalne teologije i »slabe misli« Giannija Vattima. Unutar Vattimovih ideja pronalazimo nekoliko ključnih tema u kojima se nalaze odjeci radikalne teologije, odnosno koje su bliske temama radikalne teologije.

Gianni Vattimo je, u najeminentnijem smislu riječi, analizirao i produbio ono što su analizirali i predložili velikani i začetnici postmoderne misli Friedrich Nietzsche i Martin Heidegger. Polazeći od kritike velikih priča moderne, odnosno Nietzscheove kritike kršćanstva i Heideggerove kritike zapadne metafizike, Vattimo pokušava dokučiti u čemu bi se sastojao pravi filozofski put, odnosno kako bi danas trebao izgledati Nietzscheov »nadčovjek « te kako bi uopće trebalo postaviti pitanje o smislu bitka. Prema Nietzscheu i Heideggeru, temelji naše egzistencije i metafizike su uzdrmani i suvremeni čovjek postmoderni čovjek - nema više čvrstog i sigurnog oslonca. ${ }^{9} \mathrm{U}$ tom kontekstu Vattimo ističe da je jedina prava prilika za postmodernog čovjeka nihilizam. Naime, kada postmoderni čovjek shvati da nema nikakvog temelja, tek onda može biti u stanju prihvatiti nihilizam kao jedinu pravu priliku za postmodernog čovjeka. ${ }^{10}$ Vattimo smatra da nihilizam kao prilika ima političko-zbiljski i egzistencijalni smisao. ${ }^{11} \mathrm{~S}$ jedne strane, nihilizam prepoznaje umjetno stvorene »vrhovne vrijednosti« koje određuju političke i zbiljske strukture, tako da ih tumači kao nestvarne, bez temelja, odnosno da ih »derealizira «, ${ }^{12}$ a s druge strane poziva na novu vrstu egzistencije unutar koje odustajemo od pretenzije da povijesti neprestano dodjeljujemo »metafizičku i teologijsku težinu i odlučnost «. ${ }^{13}$ Radi se o oproštaju od utemeljujućih zasada moderne:

»Nietzscheov potpuni nihilizam ima to fundamentalno značenje; poziv koji nam stiže iz svijeta kasne moderne poziv je na oproštaj. « ${ }^{14}$

Oproštaj je u srži Vattimovog projekta: oprostiti se od svih mogućih čvrstih temelja, odnosno oslabiti sve temeljne zasade moderne na tragu Heideggera $\mathrm{i}$ Nietzschea. Iz tih razloga, Vattimova središnja misao može se nazvati slabom mišlju (pensiero debole).Vattimova teza ovako glasi:

»Dakle, slaba se misao sastoji u prijedlogu interpretacije povijesti. S Heideggerom kažem 'povijesti bitka'. I ako ima ta povijest kakav smisao, tada je to upravo povijest slabljenja, to jest rasterećenje struktura za koje smo vjerovali da su jake - bitak, subjektivnost, moć itd. - u smislu manje kategoričnosti. « ${ }^{15}$

Vattimo je, također, jedan od onih autora koji su svjesni da je pitanje religije ponovno u središtu istraživanja. U tekstu u kojem iznosi vlastitu ispovijest vjere, nalazi šest razloga vraćanja religije: 1 . smrt bliskih osoba; 2 . starenje; 3 . projekt povijesti koji nije uspio uspostaviti pravednost; 4. nemoć tehnike pred problemima bioetike i nasilja; 5. politički preokreti prema kojima vatikanska politika sudjeluje u slabljenju komunizma; 6. filozofski preokreti koji su smatrali da su konačno riješili pitanje religije. ${ }^{16}$ Heideggerov projekt destrukcije povijesti zapadne metafizike, odnosno njegova izvorna potraga za istinskim postavljanjem pitanja o smislu bitka, postala je ishodišna misao pomoću koje je postmoderna misao prepoznala kraj metafizike. Samim time oslobodio se prostor za kršćanstvo:

$»$ Rečeno riječima koje su bliže mom filozofskom iskustvu: ponovno otkriće kršćanstva moguće je zbog raspada metafizike - to jest zbog kraja pretenzija jedne kulture, europske, koja je povjerovala da je otkrila i realizirala istinsku 'prirodu' čovjeka. «17 
Nihilizam, odnosno urušavanje temelja moderne, kojim se Vattimo oprašta od moderne, otvorio je prostor za pitanja o religiji. U Vattimovoj misli možemo primijetiti neke elemente radikalne teologije. Stoga, otvaramo tri Vattimove teme koje su pod utjecajem radikalne teologije: nereligiozno kršćanstvo, kenoza i Crkva.

\subsection{Nereligiozno kršćanstvo kao radikalna teologija}

Radikalna teologija bi se u Vattimovom filozofijskom spektru mogla nazvati nereligioznim kršćanstvom. ${ }^{18}$ Smrt Boga u nereligioznom kršćanstvu odnosi se na smrt autoriteta. ${ }^{19}$ Nereligiozno kršćanstvo je oslobođenje od bilo kakvih autoriteta, otvaranje subjekta neautoritativnoj istini, konačna sloboda. Ta se sloboda odnosi i na samu ideju »slobode od istine «. ${ }^{20}$ Naime, ako nešto ili netko određuje što je istina koja vrijedi za sve, onda se ne radi o slobodi, nego o vrsti prisile. Ukoliko objektivna istina postoji, a Nietzsche i Heidegger su, smatra Vattimo, pokazali da ne postoji, utoliko onda uvijek postoji mogućnost manipulacije jer će netko uvijek pretendirati na istinu smatrajući da ima povlašteni položaj u tumačenju i posjedovanju nje same. Vattimo upozorava:

»Poslije svega, ako stvarno postoji objektivna istina onda će se uvijek naći netko tko je više posjeduje od mene i na taj način je ovlašten da nametne njezinu zakonsku obvezu u odnosu na mene. ${ }^{21}$

Nadalje, ta sloboda nikada nije u potpunosti priklonjena nekoj ideji ili autoritetu. Dapače, radi se o slobodi koja je uvijek negdje »između« prihvaćanja i odbijanja istine, tj. nekog metafizičkog koncepta kao polazišta. Naime, Vattimo smatra da se u suvremenom shvaćanju slobode radi o dijalektici pripadanja i izmještenosti:

Ne treba zaboraviti da niti ideja napretka nije lišena kritike. Lino Veljak na sljedeći način opisuje slom ideje napretka: »Ono što je u našem kontekstu od prvenstvene važnosti jest potpun poraz ideje napretka, slom koji predstavlja naknadno opravdanje skepse što se s raznih strana i s raznolikim motivima iskazivala u odnosu na sve varijante konstitutivnog momenta duha moderne, a to je upravo ideja napretka.« Vidi Lino Veljak, »'Meka ontologija' i kraj moderne «, Filozofska istraživanja, god 22 (2002), sv. 85-86, br. 2-3, str. 407414, str. 408.

10

Usp. Gianni Vattimo, Kraj moderne, Matica hrvatska, Zagreb 2000., str. 19.

11

Usp. ibid., str. 29.

12

Usp. ibid., str. 28.

13

Ibid., str. 29.

14

Ibid.
16

Usp. Đ. Vatimo [G. Vattimo], Vjerovati da vjeruješ, str. 10-17.

17

Ibid., str. 53.

18

O sličnostima koje postoje između Vattima i radikalne teologije pisali su Frederiek Depoortere i Anthony Sciglitano. Usp. bilješku br. 1 i: Anthony C. Sciglitano, Jr., »Contesting the World nad the Divine: Balthasar's Trinitarian 'Response' to Gianni Vattimo's Secular Christianity«, Modern Theology 23 (4/2007), str. 525-559. doi: https:/ doi.org/10.1111/j.1468-0025.2007.00408.x.

19

Usp. G. Vattimo, After Christianity, str. 104-105.

20

Gianni Vattimo, »Toward a Nonreligious Christianity«, u: J. Caputo, G. Vattimo, After the Death of God, str. 37.

21

Ibid., str. 37.

15

Gianni Vattimo, Čitanka, Antibarbarus, Zagreb 2008., str. 253. 
»Živjeti u ovom raznolikom svijetu znači iskusiti slobodu kao neprestanu oscilaciju između pripadanja i izmještenosti.«22

Ovakva definicija nereligioznog kršćanstva djelomično se podudara s onom radikalne teologije. Čini se da Vattimova definicija proširuje tezu radikalne teologije o prihvaćanju Božje smrti na tezu o prihvaćanju smrti bilo kojeg autoriteta. Na taj način Vattimo prihvaća Heideggerov koncept tumačenja kakav sada u potpunosti dolazi do izražaja. Nema isključivog pretendiranja na istinu, nema univerzalnog tumačenja, nema uporišta, niti kršćanskog niti metafizičkog, koje bi nas moglo ovlastiti da s autoritativne pozicije tumačimo bilo što. On na sljedeći način opisuje Heideggerov koncept tumačenja:

»Ne mogu precizno reći kako stvari stoje, nego samo kakve su s ove točke gledišta, kakve se meni čine i kakve ja mislim da jesu. «23

Prema Vattimu, ne postoji više neka određena dominantna hermeneutika, nego

»... hermeneutička pluralnost koja je navalila u kasnoj moderni kao rezultat ne metafizičkog ispražnjenja Božjeg bitka u svijet, nego poruke o slabljenju Boga koji je postepeno prodirao u svijest Zapada ${ }^{24}$

Drugim riječima, klasična objektivnost moderne za Vattima je prošlost:

»Kršćanstvo proglašava kraj platoničkog ideala objektivnosti. Ne može biti vječne poruke formi izvan nas samih koja nas spašava, nego samo pogled usmjeren k nutrini i potraga duboke istine unutar svih nas«. ${ }^{25}$

Sažeto, ovako bi mogla glasiti definicija Vattimove radikalne teologije: to je teologija koja je proglašavanjem smrti autoriteta omogućila slobodu subjekta i mnoštvo različitih autentičnih i legitimnih hermeneutika. U teološkom diskursu ovakva pozicija nailazi na različite probleme. Naime, teologija Božje smrti, a onda i Vattimovo tumačenje kršćanskog Boga, temelji se na koncepciji koja se ne podudara s onom teološkom. Problem je u tome što radikalna teologija zanemaruje ostale teološke aspekte kršćanskog pristupa Bogu koji su ponovno dobili na važnosti u tzv. postmodernoj teologiji. Naime, Bog negativne teologije, apofatičke, liberalne, feminističke ili pak crnačke teologije nipošto ne može odgovarati onome teološkom pristupu kojeg radikalna teologija kritizira. Stoga, nedostatak teološkog koncepta o Bogu radikalne teologije, a onda i filozofskog pristupa Giannija Vattima, u tome je što ne uočava kritiku kršćanskog Boga unutar same kršćanske teologije.

\subsection{Radikalna kristologija}

Kao što smo već napomenuli, za Vattima svaka metafizika fungira prema principu nasilja. Ako postoji univerzalna istina i njezino univerzalno tumačenje, onda se umanjuje sloboda pojedinca jer se istina nasilno posreduje pojedincu. Za Vattima je kršćanstvo svojevrsno nasilje nad pojedincem. Vattimo smatra da je svako izricanje istine istovremeno i pokušaj uspostave kontrole. ${ }^{26}$ No ako prihvatimo nereligiozno kršćanstvo, odnosno radikalnu teologiju kao oslobođenje od autoritativnog i dalekog Boga, što nam preostaje? Preostaje nam milosrđe. Istinu će zamijeniti milosrđe kao vid nove kršćanske egzistencije oslobođene bilo kakvog autoriteta. Milosrđe je, u tom smislu, »prisutnost Boga«. ${ }^{27}$ Onaj tko u punom smislu riječi ozbiljuje prisutnost Boga i u potpunosti shvaća svoju egzistenciju kao milosrđe prema drugima je Isus Krist. Krist je čista suprotnost svome Ocu. Dok je Bog Otac Bog nasilja i 
autoriteta, Krist je simbol nenasilja, pluralnosti interpretacija i konkretnog aktivnog milosrdnog aktivizma. ${ }^{28} \mathrm{Na}$ taj način Vattimova radikalna kristologija kritizira teologiju nasilja na temelju filozofsko-teološkog promišljanja o Kristu nenasilja. U radikalnoj teologiji Vattimov pristup odnosi se na nenasilnog Krista koji živi kao čovjek za druge, kao onaj koji aktivno ostvaruje princip milosrđa. Osim toga, u Vattimovom nereligioznom kršćanstvu istina, koja se unutar kršćanstva otkriva kao milosrđe, i bitak, koji nakon Nietzscheove i Heideggerove kritike zapadne metafizike fungira kao događaj, su neodvojivo povezani. ${ }^{29}$ Stoga, možemo zasigurno reći da Vattimo predlaže milosrđe kao temelj kršćanstva, tj. kao ono što ostaje kada se oslobodimo velikih priča kršćanstva. Time je zapravo Vattimo reducirao ne samo vjeru nego i cjelokupno kršćanstvo na milosrđe jer se

»... suština objave svodi na milosrđe, a sve drugo neka bude prepušteno ne-konačnosti različitih historijskih iskustava i mitologija koje su se svaki put pokazale kao obavezujuće za pojedina historijska čovještva«. ${ }^{30}$

Ovime Vattimo nipošto ne odbacuje crkvenu tradiciju i biblijske pripovijesti, ali predlaže da u svakoj povijesnoj situaciji prakticiranje milosrđa zahtijeva i »demitizirajuću sekularizaciju «, ${ }^{31}$ tj. neprihvaćanje kulturoloških, duhovnih i drugih mitova.

U tumačenju Vattimove kristologije suočavamo se sa sljedećim problemom. Naime, nije li njegov prijedlog prihvaćanja Krista ne-nasilja i odbacivanja Boga Oca koji predstavlja dalekog i tradicionalnog Boga ujedno i izricanje istine i pokušaj uspostave kontrole? Derridain učenik i američki filozof religije John Caputo zamjera Vattimu i radikalnoj teologiji što nakon proglasa Božje smrti kao proglasa smrti velikih priča moderne ipak uspostavljaju svoju veliku priču. Caputo na sljedeći način ocjenjuje radikalnu teologiju, u koju svrstava i Vattima:

»Moja je dugotrajna zabrinutost da su teologije Božje smrti same jedva prikrivene grand récits. To su teologije povijesti koje pričaju veliku priču kako smo od religije Oca u Židovstvu došli do religije Sina u Novom zavjetu, pa do religije Duha u moderni (Altizer) i postmoderni (Taylor) što je Posljednja Priča. « ${ }^{32}$

22

Gianni Vattimo, Transparentno društvo, Algoritam, Zagreb 2008.

23

G. Vattimo, »Toward a Nonreligious Christianity«, str. 28.

24

Matthew Harris, »Gianni Vattimo and Thomas J. J. Altizer on the Incarnation and the Death of God: a Comparison«, Minerva - An Internet Journal of Philosophy 15 (2011), str. 17.

25

G. Vattimo, »Toward a Nonreligious Christianity $\ll$, str. 31.

26

Usp. ibid., str. 43.

27

Ibid., str. 45 .
28

Vattimo u tumačenju nasilnog Boga slijedi Renea Girarda. O Vattimovom tumačenju Boga Oca vidi vrlo instruktivan članak Matthewa Harrisa. Usp. Matthew Harris, „God the Father in Vattimo's Interpretation of Christianity«, Heythrop Journal 54 (2013), str. 891-903.

29

G. Vattimo, After Christianity, str. 112.

30

G. Vattimo, Vjerovati da vjeruješ, str. 70 .

31

Ibid., str. 73 .

32

John Caputo, »spectral Hermeneutics: On the Weakness of God and the Theology of the Event«, u: J. Caputo, G. Vattimo, After the Death of God, str. 68-69. 
Te su teologije za Caputa teologije »s kršćanskim podrijetlom koje usmjeravaju na nauk o Trojstvu i utjelovljenju« ${ }^{33}$ Dakle, iako kritizira Boga Oca kao dominantnog i tradicionalnog Boga koji uspostavlja kontrolu i onemogućava ostvarivanje slobode, Vattimo ipak u određenoj mjeri sam izriče svojevrsnu veliku priču o Kristu nenasilja kakav odgovara novom shvaćanju Crkve i kršćanske egzistencije. Slaba misao je kritikom jake misli izišla iz vlastite slabosti, odnosno prema Caputovoj procjeni, postala je »prejaka«:

»Kada slaba misao prodire u svoju vlastitu priču, kada ona nađe veliku priču u kojoj priča veliku pripovijetku o prijelazu od snažne metafizičke misli do slabe, od otuđenog Boga do utjelovljenog Boga ovdje na zemlji, i od pravovjerne kršćanske dogme do suvremene sekularizirane istine kršćanstva u postmodernom svijetu, tada je slaba misao narasla u malo prejaku. « ${ }^{34}$

Nadalje, Vattimo je tumačenje uloge Krista u nereligioznom kršćanstvu potkrijepio tumačenjem kenoze. »Kenoza« ili »ispražnjenje« je teološki pojam kojim se izražava Kristovo preuzimanje ljudske naravi. ${ }^{35}$ Vattimo polazi od stajališta da je kenoza slabljenje Boga, odnosno da je »treba tumačiti kao znamenje da ima nenasilni i ne-apsolutni Bog postmetafizičke epohe « ${ }^{36}$ Kenoza se nalazi unutar filozofsko-teološke tradicije koja oslabljuje čvrste temelje zapadne metafizike. To je prva značajka kenoze. Druga značajka kenoze, prema Vattimu, tiče se relacije između kenoze i sekularizacije. Vattimo smatra da je sekularizacija pozitivna posljedica Isusovog života i djelovanja. Nenasilni Krist ili Krist milosrđa, kakvog zagovara Vattimo, sekularizira Boga nasilja. Drugim riječima, Krist je sekularizirani Otac. Vattimo ovako formulira ovu tezu:

»Ako je prirodno sakralno onaj nasilni mehanizam koji je Isus htio razotkriti i demantirati, posve je moguće da je sekularizacija - koja je i gubitak svjetovnog autoriteta Crkve, osamostaljenje čovjekova uma od ovisnosti o apsolutnom Bogu, prijetećem Sucu, toliko transcendentalnome našim idejama o dobru i zlu da se čini kapricioznim i bizarnim suverenom - upravo pozitivni učinak Isusova učenja, a ne način udaljavanja od njega. « ${ }^{37}$

Krist, sekularizirani Bog, ujedno ima i proročku ulogu kritiziranja svih autoritarnih i neispravnih tumačenja koja počivaju na staroj zasadi moderne. Stoga ne čudi što Vattimo Kristu pripisuje također ulogu »demistifikatora«:

»Ako se potrudim ozbiljno razumjeti smisao kenoze, slijedeći i ono do čega je došla fillozofska kritika metafizičkog načina mišljenja, tada shvaćam da je ovdje demistifikator sam Krist, a da raskrinkavanje što ga on najavljuje (ili na čiji istinski smisao konačno pokazuje, budući da kenosis započinje sa samim stvaranjem i Starim zavjetom), to, dakle, raskrinkavanje predstavlja samo značenje povijesti spasenja. «38

Treća značajka kenoze proizlazi upravo iz razumijevanja Krista kao demistifikatora. Naime, Krist demistifikator raskrinkava sve forme istine koje funkcioniraju po principu nasilja. Time su dogmatski izričaji vjere, zapovijedi, crkvene prakse, liturgija, kao i sama narav Crkve dovedeni u pitanje. Charles Morerod smatra da se u Vattimovom shvaćanju kenoze »vidi klica nestanka svake objektivne istine i svake nepromjenjive moralne norme « ${ }^{39}$ Krist kao sekularizirani Otac suprotstavlja se samom sebi raskrinkavajući temeljne zasade kršćanstva. Ostvarilo se Vattimovo predviđanje prema kojem se sekularizirani Otac okreće protiv samoga sebe:

»No, neće li se to raskrinkavanje, za koje je moderni um mislio da ga treba obaviti u odnosu spram objave, okrenuti upravo, i prije svega, protiv same ideje objave, to jest protiv božanskog uplitanja u historiju? Protiv ideje stvaranja, čovjekove ovisnosti o božanstvu itd.?« ${ }^{40}$

Vattimovo tumačenje kenoze blisko je tumačenju kenoze radikalne teologije, no ne bismo mogli ustvrditi kako se radi o istovjetnoj konstataciji. ${ }^{41} \mathrm{Kod}$ 
Vattima se ipak ne radi o kenozi kao procesu Božjeg umiranja na križu, nego se radi o novoj vrsti Božje egzistencije u imanenciji, odnosno u Kristu koji nas je oslobodio nasilja Boga Oca. Osim toga - a to bi bila druga razlika u tumačenju kenoze Vattima i radikalne teologije - kenoza je za Vattima isto što i utjelovljenje, dok su za radikalnu teologiju utjelovljenje i smrt na Križu dio jednog te istog procesa kenoze u kojem Bog umire.

\subsection{Radikalno tumačenje Crkve}

Isus Krist demistifikator demistificira objavu, Učiteljstvo Crkve i temeljne istine vjere. Ako Krist raskrinkava temeljne zasade kršćanskog nauka, što prema Vattimu preostaje? Na koji način Vattimo vidi mogućnost jedne nove demistificirane Crkve, odnosno novog kršćanskog života? Kakva bi to trebala biti Crkva i kakav bi to trebao biti vjernik? Koje su karakteristike Vattimovog shvaćanja ekleziologije? Navodimo dvije glavne karakteristike Vattimovog shvaćanja Crkve: ekleziologija bez autoriteta i u unutarkršćanskom smislu poništavanje zajednice, a u vancrkvenom smislu poništavanje pojedinca.

Dakako, radi se o već spomenutoj Vattimovoj ideji nereligioznog, tj. sekulariziranog kršćanstva, pa u tom smislu možemo govoriti i o Vattimovoj sekulariziranoj ekleziologiji, oslobođenoj autoriteta, morala, hijerarhije i sakramenata. Nikola Dogan prepoznaje Vattimovu ekleziologiju na sljedeći način:

»G. Vattimo načelno pod pojmom nereligioznoga kršćanstva razumije necrkveno i neautoritarno kršćanstvo, s posebnim naglaskom na odbojnosti prema autoritarizmu pape Ivana Pavla II. Nereligiozno kršćanstvo za Vattima nije organizirano kršćanstvo, ono nema dogmi, nema moralnih i disciplinskih normi, nema hijerarhije, nema 'istine' vjere, nema sakramenata, nema svetoga i slično. Crkva je velika humanitarna zajednica onih koji žive postmodernim načinom kršćanskoga života. ${ }^{42}$

Objava je bez svojih vanjskih formi, »sa svim svojim tovarom mitova, posvećena samo našoj pouci, a smisao svega toga je upravo ljubav spram Boga i spram bližnjega« ${ }^{43}$

Druga karakteristika Vattimovog prijedloga bila bi, u dogmatskom smislu, poništavanje zajednice nauštrb pojedinca, a u pastoralnom smislu poništava-

33

Ibid., str. 79.

34

Ibid., str. 85 .

35

Za tumačenje kenoze vidi: Giovanni Iammarrone, »Kenoza«, u: Luciano Pacomio, Vito Mancuso (ur.), Enciklopedijski teološki rječnik, Kršćanska sadašnjost, Zagreb 2009., str. 485-488; Karl Rahner, Herbert Vorgrimler, »Kenoza«, u: Karl Rahner, Herbert Vorgrimler (ur.), Teološki rječnik, U pravi trenutak, Đakovo 2004., str. 241.

36

G. Vattimo, Čitanka, str. 224.

37

Ibid., str. 225-226.

38

Đ. Vattimo [G. Vattimo], Vjerovati da vjeruješ, str. 57-58.
39

Charles Morerod, »'Religijska' postmoderna: Gianni Vattimo«, Obnovljeni život 68 (2/2013), str. 170 .

40

Đ. Vattimo [G. Vattimo], Vjerovati da vjeruješ, str. 58.

41

O usporedbi Vattimovog i Altizerovog tumačenja kenoze više vidi u: M. Harris, »Gianni Vattimo and Thomas J. J. Altizer on the Incarnation and the Death of God: a Comparison«, str. 5-7.

42

Nikola Dogan, »Nereligiozno kršćanstvo u 'slaboj misli' Giannija Vattima«, Crkva u svijetu 40 (4/2005), str. 532.

43

Đ. Vatimo [G. Vattimo], Vjerovati da vjeruješ, str. 71 . 
nje pojedinca nauštrb zajednice. Što to znači? To znači da u crkvenom nauku i dogmama ne postoji neka opća istina koju se ne bi moglo demitizirati i demistificirati. Individualno shvaćanje osobnog, duhovnog iskustva je iznad bilo kakvog autoritativnog tumačenja svetoga u kršćanstvu. Religija se u tom smislu transformira u privatno područje. Jure Strujić smatra da Vattimo »budućnost religije vidi u individualnim, 'privatnim' i osobnim interpretacijama religioznog doživljaja «. ${ }^{44}$ Slijedeći takvu vrstu interpretacije, proizlazi i činjenica da Vattimo učiteljstvo Crkve smatra kamenom spoticanja istinskog kršćanstva. No pitamo se na koji način preostaje kršćanima tumačiti Božju poruku u vlastitom životu, a da se kršćanski život ne pretvori u neku vrstu 》solipsističkog « kršćanstva potpuno izoliranog od zajednice? Vattimo predlaže da se vjernici međusobno korigiraju vlastitim tumačenjima, omogućujući jedni drugima put u slobodi njihove interpretacije. U drugom, pastoralnom smislu pojedinac nije više toliko bitan, nije ni njegovo shvaćanje religije, nego je najbitnije zajedničkim snagama, kao u prvoj kršćanskoj zajednici, preobraziti društvo. ${ }^{45}$

Na temelju Vattimovog razumijevanja Crkve možemo zaključiti da je blisko shvaćanju radikalne teologije. Božja smrt označava i smrt bilo kakvog crkvenog autoriteta koji zakriva pravi smisao autentične egzistencije. Božja smrt je za Vattima izazov koji otvara vrata novoj vrsti kršćanske egzistencije, odnosno novoj viziji Crkve.

\section{Zaključak}

Filozofija religije Giannija Vattima ne isključuje temeljne premise radikalne teologije, nego ih, naprotiv, prihvaća i nadopunjuje. Iako, prema našem mišljenju, Vattimove ideje, kao i ideje radikalne teologije, ne uzimaju dovoljno u obzir kršćansku teološku tradiciju, one ipak naznačuju da unutar okvira šire kulture, ali i same teologije, postoje tendencije temeljitog preispitivanja osnovnih kršćanskih tema. Ne treba, u tom smislu, zanemariti veliki doprinos Drugog vatikanskog koncila proučavanju fenomena vjere i ateizma.

Radikalna teologija je inzistirala na teološkom anticipiranju Božje smrti temeljem kenoze koja se ostvaruje u utjelovljenju i smrti na križu. Na taj način su autori radikalne teologije, iako polazeći od različitih premisa, ostvarili svojevrstan dijalog s ateizmom koji je, posebice u svojim djelima iz filozofije religije, nastavio i produbio Gianni Vattimo svojom glavnom tezom o nereligioznom kršćanstvu.

U postmodernom ili postmetafizičkom razdoblju, nereligiozno kršćanstvo pretpostavlja smrt bilo kakvog autoriteta. Štoviše, Vattimovo shvaćanje kenoze, kao i tumačenje kenoze u radikalnoj teologiji, upućuje na razumijevanje Boga koji se približava čovjeku oslabljujući čvrste pozicije klasične kršćanske teologije. Stoga se Vattimovo prihvaćanje Nietzscheovog proglasa Božje smrti može tumačiti u kontekstu nestanka autoriteta i velikih priča nakon kraja moderne, a ne kao smrt Boga unutar tumačenja radikalne teologije. Iz takvih premisa proizlazi hermeneutika Crkve koja, na tragu radikalne teologije, zagovara razgovor između pojedinaca u zajednici, kritično odbacujući sve crkvene autoritete. Takvim kritičnim pristupom Vattimo cjelokupno kršćanstvo reducira na ljubav i milosrđe koje, kao život za druge, posjeduje potencijal za promjenu nepravednih odnosa u društvenom poretku. I Vattimovo nereligiozno kršćanstvo i radikalna teologija pronalaze sličan modus kršćanske egzistencije nakon Nietzscheove kritike kršćanstva i Heideggerove destrukcije povijesti zapadne metafizike. 


\title{
Zoran Turza \\ Echoes of Radical Theology in the Nonreligious Christianity of Gianni Vattimo
}

\begin{abstract}
This paper focuses on the relation between "weak thought" of Gianni Vattimo and theological movement called "radical theology" or "death of God theology". The first part consists of an overview of the main representatives of radical theology which seeks to break up with classic theology, considered to begin with transcendent and distant God. The second part provides an overview of the three Vattimo's subjects that coincide with the thesis of radical theology: nonreligious Christianity, kenosis and Church. Nonreligious Christianity as the liberation of every authority functions as a wide thesis of radical theology about liberation of the classical approach to God. On the other hand for Vattimo, kenosis as self-emtpying of the God Father confirms the weakening of strong stories of the modern, and the classical model of the Church as well. At the same time kenosis in the radical theology confirms the death of God.
\end{abstract}

\section{Keywords}

death of God, radical theology, Gianni Vattimo, nonreligious Christianity, kenosis

44

Jure Strujić, »Kršćanstvo na postmoderni način. Slabo i post-metafizičko kršćanstvo Giannija Vattima«, Crkva u svijetu 49 (4/2014), str. 448.
45

U tom kontekstu Vattimo izlaže tezu o »katokomizmu«. O značenju ove teze vidi više u: ibid., str. 452. 